\title{
Softwood Grafting in Jamun (Syzygium cumini Skeel) under Open and Controlled Conditions
}

\author{
R. Praveenakumar ${ }^{1 *}$, M. Chandre Gowda ${ }^{1}$, S. Mounashree ${ }^{2}$ and A. Vidya ${ }^{1}$ \\ ${ }^{1}$ Department of Horticulture, College of Agriculture, UAS, GKVK, Bengaluru-560065, \\ Karnataka, India \\ ${ }^{2}$ Department of Fruit sciences, College of Horticulture, Mudigere, UAHS, Shivamoga-577132, \\ Karnataka, India \\ *Corresponding author
}

\section{A B S T R A C T}

\begin{tabular}{|c|}
\hline Keywords \\
\hline $\begin{array}{l}\text { Softwood grafting, } \\
\text { Jamun, Low cost } \\
\text { polyhouse, Survival, } \\
\text { Season }\end{array}$ \\
\hline Article Info \\
\hline $\begin{array}{l}\text { Accepted: } \\
22 \text { April } 2018 \\
\text { Available Online: } \\
10 \text { May } 2018\end{array}$ \\
\hline
\end{tabular}

\section{Introduction}

Jamun is an important minor indigenous underexploited, arid zone fruit crop because of its hardy nature, high yielding potential besides its nutritious fruits, used for making delicious and nutritious squash, jams, jellies, juice and wines etc. The seeds have medicinal properties and used for diabetes. It is found growing wild throughout India; the trees are mostly planted as wind breaker on the orchard boundary or along the avenues. Lack of improved varieties, long gestation period that the plants obtained from seeds taken for fruiting are main responsible factors for not cultivating this crop on orchard scale despite its high potential as a dry land horticulture fruit crop and its multifarious uses.

The research work on vegetative propagation of the crop is rather scanty and sporadic. Singh et al., (1979) tried budding and Madalageri et al., (1991) tried softwood grafting (vegetative propagation) of Jamun under open conditions. Hence, attempt was made to evaluate possibility of propagation of Jamun by softwood grafting in different seasons under different growing conditions (open, low cost polyhouse and shade net conditions). 


\section{Materials and Methods}

An investigation was conducted on Softwood Grafting in Jamun (Syzygium cumini Skeel) under open and controlled conditions at the Department of Horticulture, University of Agricultural Sciences, Gandhi Krishi Vignana Kendra, Bengaluru. Geographically, the experimental site was located at $12^{\circ} 58^{\prime} \mathrm{N}$ and $77^{\circ} 35^{\prime} \quad \mathrm{E}$ and $930 \mathrm{MSL}$. Experiment conducted to assess the vegetative growth and grafting success and survival percentage of jamun with five treatments (months), and three sub treatment (growing condition) with three replications using split plot design. Jambunerale was used both as a rootstock and scion under Bangalore region, during the period from the year April 2016 to August 2016.

To raise the nursery, fresh seeds were sown in a seed pan for germination. When seedlings attained four leaf stage they were transplanted to polyethylene bags containing a potting mixture of red sandy loam soil, sand and farm yard manure in the ratio of 3:1:1, respectively. The seedlings were grown for one year and softwood grafting during four different months softwood grafting over the year was done with scion procured from 15years old healthy Jamun tree. The vegetative growth such as sprouting and leaf emergence of graft success and survival per cent was recorded at 30 and 60 days after softwood grafting of Jamun.

\section{Results and Discussion}

The difference in least number of days taken for sprouting and least number of days taken for leaf emergence obtained under different seasons in different growing condition are presented in (Table 1). The data in respect of least number of days taken for sprouting $(15.33,15.07)$ under the month of June (M3), low cost polyhouse (C1) respectively. This may be due to the favorable climatic conditions during these months such as moderate temperature $\left(28^{\circ} \mathrm{C}\right.$ to $\left.32^{\circ} \mathrm{C}\right)$ and ideal relative humidity ( $74 \%$ to $78 \%$ ). The temperature and relative humidity activates the cambium cells during monsoon.

The new callus tissue arising out of the cambial region consists of thin walled turgid cells which are easily desiccated and die off due to dry weather and higher relative humidity can protect such cells in the cambial region of the graft union (Hartaman and Kester, 1989).

Minimum number of the days for sprouting after grafting was also recorded by recorded Hulamani and Nachegowda (1981) in mango. This might also be attributed to the fact that easy swelling of buds (both axillary and apical) which would have caused quick healing of union, leading to the better sprouting of grafts.

The least number of leaf emergence was recorded in the month of June $\left(\mathrm{M}_{3}\right)$ (25.00), low cost polyhouse $\left(\mathrm{C}_{1}\right)$ (26.27) (Table 1) because of favorable climatic conditions like high relative humidity and increase in translocation of food materials. Similar results were reported by Mohammad and Mohammad (2005).

The highest of graft success per cent (90.85, 88.20) was found under the June $\left(\mathrm{M}_{3}\right)$, low cost polyhouse $\left(\mathrm{C}_{1}\right)$, respectively (Table 2 ). Could also be correlated to higher cell activity and active growth of both stock and scion in the prevailing favorable climatic conditions. The same results were recorded in jamun by Ghojage et al., (2011). The environmental conditions for low cost polyhouse grafts can be readily controlled, thereby permitting greater reliability of grafting over long period compared to open field grafting operation (Hartman and Kester, 1979). 
Table.1 Effect of season and growing conditions for softwood grafting on first Sprouting and first leaf emergence in Jamun

\begin{tabular}{|c|c|c|}
\hline Treatments & Days taken for first Sprouting & Days taken for first leaf emergence \\
\hline \multicolumn{3}{|c|}{ Months (M) } \\
\hline $\mathrm{M}_{1}$-April & 18.44 & 32.00 \\
\hline $\mathbf{M}_{2}$-May & 16.11 & 28.44 \\
\hline M ${ }_{3-J u n e}$ & 15.33 & 25.00 \\
\hline $\mathrm{M}_{4}-\mathrm{July}$ & 15.44 & 26.56 \\
\hline$M_{5}$-August & 20.33 & 25.70 \\
\hline S.Em \pm & 00.80 & 00.61 \\
\hline C.D at $5 \%$ & 02.60 & 02.00 \\
\hline \multicolumn{3}{|c|}{ Condition $(\mathbf{C})$} \\
\hline $\mathrm{C}_{1}$-Low cost polyhouse & 15.07 & 26.27 \\
\hline $\mathrm{C}_{2}$-Shade net & 17.47 & 27.93 \\
\hline $\mathrm{C}_{3}$-Open field & 18.87 & 28.42 \\
\hline S.Em \pm & 00.62 & 00.49 \\
\hline C.D at $5 \%$ & 01.83 & 01.44 \\
\hline \multicolumn{3}{|c|}{ Interaction $(\mathbf{M} \times \mathbf{C})$} \\
\hline $\mathrm{M}_{1} \mathrm{C}_{1}$ & 15.21 & 30.33 \\
\hline $\mathrm{M}_{1} \mathrm{C}_{2}$ & 15.67 & 33.00 \\
\hline $\mathbf{M}_{1} \mathbf{C}_{3}$ & 19.00 & 32.67 \\
\hline $\mathrm{M}_{2} \mathrm{C}_{1}$ & 20.67 & 27.00 \\
\hline $\mathrm{M}_{2} \mathrm{C}_{2}$ & 14.33 & 28.33 \\
\hline $\mathrm{M}_{2} \mathrm{C}_{3}$ & 16.00 & 30.00 \\
\hline $\mathrm{M}_{3} \mathrm{C}_{1}$ & 18.00 & 21.00 \\
\hline $\mathrm{M}_{3} \mathrm{C}_{2}$ & 14.00 & 26.00 \\
\hline $\mathrm{M}_{3} \mathrm{C}_{3}$ & 15.33 & 28.00 \\
\hline $\mathbf{M}_{4} \mathbf{C}_{1}$ & 16.67 & 25.00 \\
\hline $\mathbf{M}_{4} \mathbf{C}_{2}$ & 13.33 & 27.00 \\
\hline $\mathrm{M}_{4} \mathrm{C}_{3}$ & 16.33 & 27.67 \\
\hline $\mathbf{M}_{5} \mathbf{C}_{1}$ & 16.67 & 28.00 \\
\hline $\mathrm{M}_{5} \mathrm{C}_{2}$ & 18.00 & 25.33 \\
\hline $\mathrm{M}_{5} \mathrm{C}_{3}$ & 20.67 & 23.76 \\
\hline$F$ test $(p \leq 0.05)$ & $*$ & $*$ \\
\hline S.Em \pm & 01.39 & 01.10 \\
\hline C.D at $5 \%$ & 04.10 & 03.23 \\
\hline
\end{tabular}

* significant

$\mathrm{T}_{1}-\mathrm{M}_{1} \mathrm{C}_{1}$ :April + Low cost polyhouse

$\mathrm{T}_{2^{-}} \mathrm{M}_{1} \mathrm{C}_{2}$ :April + Shade net

$\mathrm{T}_{3}-\mathrm{M}_{1} \mathrm{C}_{3}$ :April + Open field

$\mathrm{T}_{4}-\mathrm{M}_{2} \mathrm{C}_{1}: \mathrm{May}+$ Low cost polyhouse

$\mathbf{T}_{5}-\mathbf{M}_{2} \mathrm{C}_{2}:$ May + Shade net

$\mathrm{T}_{6}-\mathrm{M}_{2} \mathrm{C}_{3}:$ May + Open field

$\mathrm{T}_{7}-\mathrm{M}_{3} \mathrm{C}_{1}$ :June + Low cost polyhouse

$\mathrm{T}_{8^{-}}-\mathrm{M}_{3} \mathrm{C}_{2}$ :June + Shade net

$\mathrm{T}_{9}-\mathrm{M}_{3} \mathrm{C}_{3}:$ June + Open field

$\mathrm{T}_{10^{-}} \mathbf{M}_{4} \mathrm{C}_{1}$ :July + Low cost polyhouse

$\mathrm{T}_{11^{-}-\mathrm{M}_{4} \mathrm{C}_{2} \text { :July + Shade net }}$

$T_{12^{-}}-M_{4} C_{3}$ :July + Open field

$\mathrm{T}_{13^{-}} \mathbf{M}_{5} \mathrm{C}_{1}$ :August + Low cost polyhouse

$\mathrm{T}_{14^{-}}-\mathrm{M}_{5} \mathrm{C}_{2}$ :August + Shade net

$\mathrm{T}_{15^{-}}-\mathrm{M}_{5} \mathrm{C}_{3}$ :August + Open field 
Table.2 Influence of the months of grafting, growing condition and their interactions on Grafting success and survival of jamun

\begin{tabular}{|c|c|c|}
\hline Treatments & Graft success (\%) & Graft survival (\%) \\
\hline \multicolumn{3}{|c|}{ Months (M) } \\
\hline $\mathbf{M}_{1}$-April & 68.11 & 87.05 \\
\hline $\mathbf{M}_{2}$-May & 77.58 & 91.56 \\
\hline $\mathbf{M}_{3}$-June & 90.85 & 93.67 \\
\hline$\overline{\mathbf{M}_{4} \text {-July }}$ & 82.52 & 91.36 \\
\hline $\mathbf{M}_{5}$-August & 78.34 & 88.01 \\
\hline S.Em \pm & 1.75 & 0.53 \\
\hline C.D at 5\% & 5.70 & 1.72 \\
\hline \multicolumn{3}{|c|}{ Condition(C) } \\
\hline $\mathrm{C}_{1}$-Low cost polyhouse & 88.20 & 92.01 \\
\hline $\mathrm{C}_{2}$-Shade net & 77.83 & 89.40 \\
\hline $\mathrm{C}_{3}$-Open field & 72.42 & 89.58 \\
\hline S.Em \pm & 0.90 & 0.53 \\
\hline C.D at 5\% & 2.66 & 1.56 \\
\hline \multicolumn{3}{|c|}{ Interaction $(\mathbf{M} \times \mathbf{C})$} \\
\hline $\mathbf{M}_{1} \mathbf{C}_{1}$ & 83.00 & 87.99 \\
\hline $\mathrm{M}_{1} \mathbf{C}_{2}$ & 68.00 & 85.00 \\
\hline $\mathbf{M}_{1} \mathbf{C}_{3}$ & 53.34 & 88.17 \\
\hline $\mathbf{M}_{2} \mathbf{C}_{1}$ & 85.78 & 91.48 \\
\hline $\mathbf{M}_{2} \mathbf{C}_{2}$ & 74.53 & 91.35 \\
\hline $\mathbf{M}_{2} \mathbf{C}_{3}$ & 72.44 & 91.86 \\
\hline $\mathrm{M}_{3} \mathbf{C}_{1}$ & 96.22 & 97.67 \\
\hline $\mathrm{M}_{3} \mathrm{C}_{2}$ & 91.00 & 90.40 \\
\hline $\mathrm{M}_{3} \mathrm{C}_{3}$ & 85.33 & 92.94 \\
\hline $\mathbf{M}_{4} \mathbf{C}_{1}$ & 91.67 & 92.93 \\
\hline $\mathbf{M}_{4} \mathbf{C}_{2}$ & 78.55 & 91.15 \\
\hline $\mathbf{M}_{4} \mathbf{C}_{3}$ & 77.34 & 90.00 \\
\hline $\mathbf{M}_{5} \mathbf{C}_{1}$ & 84.33 & 90.00 \\
\hline $\mathbf{M}_{5} \mathbf{C}_{2}$ & 77.06 & 89.09 \\
\hline $\mathrm{M}_{5} \mathrm{C}_{3}$ & 73.64 & 84.93 \\
\hline$F$ test $(p \leq 0.05)$ & * & * \\
\hline S.Em \pm & 2.02 & 1.19 \\
\hline C.D at $5 \%$ & 5.97 & 3.51 \\
\hline
\end{tabular}

* significant

$\mathrm{T}_{1}-\mathrm{M}_{1} \mathrm{C}_{1}$ :April + Low cost polyhouse

$\mathrm{T}_{2^{-}} \mathrm{M}_{1} \mathrm{C}_{2}$ :April + Shade net

$T_{3^{-}} M_{1} C_{3}:$ April + Open field

$\mathrm{T}_{4^{-}}-\mathrm{M}_{2} \mathrm{C}_{1}:$ May + Low cost polyhouse

$\mathrm{T}_{5}-\mathrm{M}_{2} \mathrm{C}_{2}: \mathrm{May}+$ Shade net

$\mathrm{T}_{6}-\mathrm{M}_{2} \mathrm{C}_{3}:$ May + Open field

$\mathrm{T}_{7}-\mathrm{M}_{3} \mathrm{C}_{1}:$ June + Low cost polyhouse

$\mathbf{T}_{8}-\mathbf{M}_{3} \mathrm{C}_{2}$ :June + Shade net

$\mathrm{T}_{9}-\mathrm{M}_{3} \mathrm{C}_{3}:$ June + Open field

$\mathrm{T}_{10}-\mathrm{M}_{4} \mathrm{C}_{1}:$ July + Low cost polyhouse

$\mathrm{T}_{11}-\mathrm{M}_{4} \mathrm{C}_{2}$ :July + Shade net

$T_{12}-M_{4} C_{3}:$ July + Open field

$\mathrm{T}_{13}-\mathrm{M}_{5} \mathrm{C}_{1}$ :August + Low cost polyhouse

$\mathrm{T}_{14^{-}}-\mathrm{M}_{5} \mathrm{C}_{2}$ :August + Shade net

$T_{15^{-}} M_{5} C_{3}$ :August + Open field 
Highest graft survival per cent $(93.67,92.01)$ was found in June month $\left(\mathrm{M}_{3}\right)$, low cost polyhouse $\left(\mathrm{C}_{1}\right)$ respectively (Table 2$)$. The highest graft success in June under low cost polyhouse might be due the favorable climatic condition in term of high temperature and high relative humidity values. Similar opinion was also expressed by shinde et al., (2011) in jamun.

In jamun, days taken for first sprouting, days taken for leaf emergence, graft success and survival percentage showed superior in low cost polyhouse condition under the June month, has compared to other to conditions.

\section{References}

Ghojage, A. H., Swamy, G. S. K., Kanamadi, V. C., Jagdeesh, R. C., Kumar, P. C., Patil, P. And Reddy, B. S., 2011, Effect of season on softwood grafting in jamun (Syzygium cumini, Skeels.) Acta Hort, 890.
Hartamann, H. T. And Kester, D. E., 1989, Plant Propagation Principles and practices fifth Edn., Prentice Hall Ltd., pp. 360-363.

Hulamani, N.C. And Nachegowda, N., 1981, Studies on green wood wedge grafting in some varieties of mango. The Lalbagh, 25(2): 77-79.

Madalageri, M. B., Patil, V. S. And Nalwadi, U.G., 1991, Propagation of Jamun by softwood wedge grafting. My Forest, 27: 176-178.

Mohammad H. M, And Mohammad A. F. F., 2005, Studies on Effect of Some Bio Fertilizer of Growth of Peach Seedling and Root Disease Incidence. Egypet. J. Hort., 26 (1):7-18.

Shinde S. B, Saiyad M. Y, Jadav R. G, Chavda J. C. 2011, Effect of time on softwood grafting success and survival of jamun grafts (Syzygium cimini Skeel). Intl. J. Agril Sci., 967; 7: 83-85.

Singh, V. R., Pandey I. C. And Prasad R. S., 1979, Propagation of jamun by budding. Punjab Hort. J., 19: 74-75.

\section{How to cite this article:}

Praveenakumar, R., M. Chandre Gowda, S. Mounashree and Vidya, A. 2018. Softwood Grafting in Jamun (Syzygium cumini Skeel) under Open and Controlled Conditions. Int.J.Curr.Microbiol.App.Sci. 7(05): 3019-3023. doi: https://doi.org/10.20546/ijcmas.2018.705.351 